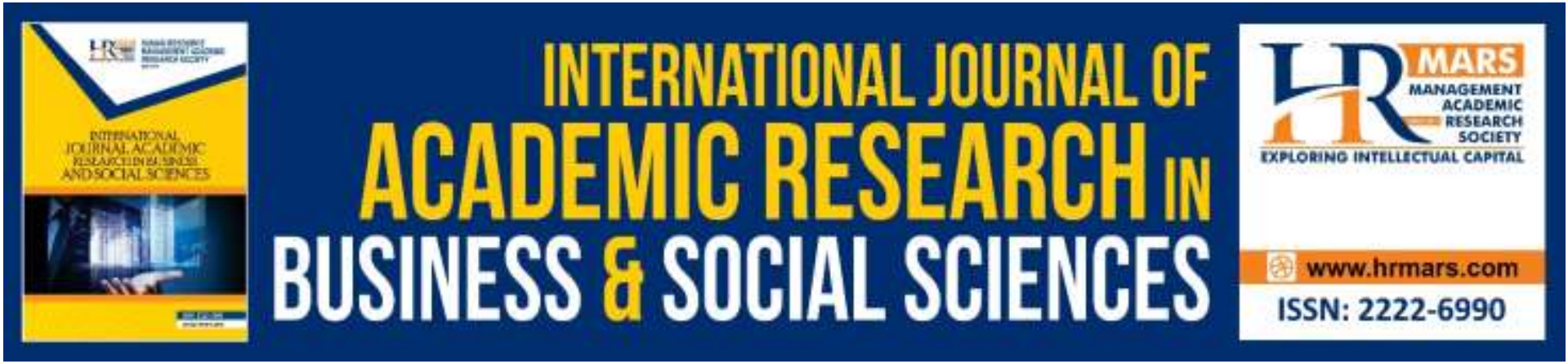

\title{
Leadership Styles in Influencing Employees' Job Performances
}

\section{Tan Bee Wen, Theresa C. F. Ho, Beni Widarman Yus Kelana, Rafidah Othman \& Obed Rashdi Syed}

To Link this Article: http://dx.doi.org/10.6007/IJARBSS/v9-i9/6269

DOI: $10.6007 /$ IJARBSS/v9-i9/6269

Received: 22 June 2019, Revised: 20 July 2019, Accepted: 09 August 2019

Published Online: 23 September 2019

In-Text Citation: (Wen, Ho, Kelana, Othman, \& Syed, 2019)

To Cite this Article: Wen, T. B., Ho, T. C. F., Kelana, B. W. Y., Othman, R., \& Syed, O. R. (2019). Leadership Styles in Influencing Employees' Job Performances. International Journal of Academic Research in Business and Social Sciences, 9(9), 55-65.

Copyright: (C) 2019 The Author(s)

Published by Human Resource Management Academic Research Society (www.hrmars.com)

This article is published under the Creative Commons Attribution (CC BY 4.0) license. Anyone may reproduce, distribute, translate and create derivative works of this article (for both commercial and non-commercial purposes), subject to full attribution to the original publication and authors. The full terms of this license may be seen at: http://creativecommons.org/licences/by/4.0/legalcode

Vol. 9, No. 9, 2019, Pg. 55 - 65

Full Terms \& Conditions of access and use can be found at http://hrmars.com/index.php/pages/detail/publication-ethics 


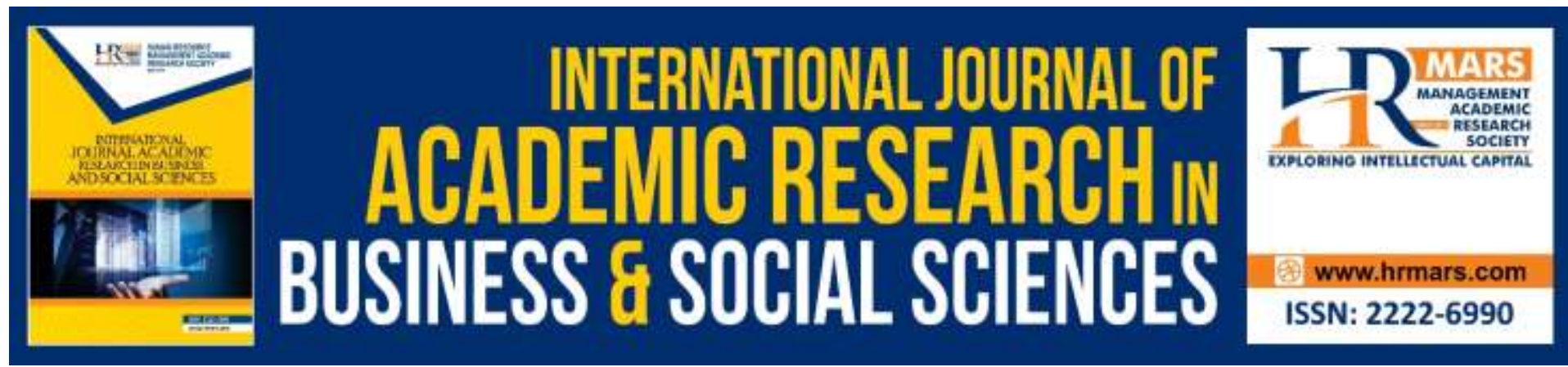

\title{
Leadership Styles in Influencing Employees' Job Performances
}

\author{
Tan Bee Wen \\ Azman Hashim International Business School, University Teknologi Malaysia \\ 81310 Skudai Johor, Malaysia
}

\section{Theresa C. F. Ho, Beni Widarman Yus Kelana, Rafidah Othman \& Obed Rashdi Syed}

Azman Hashim International Business School, University Teknologi Malaysia 54100 Kuala Lumpur, Malaysia

\begin{abstract}
As the global business environment becomes increasingly competitive, the manager's leadership style is gaining importance to drive employees' efficiencies and productivity levels. Employees are the key drivers of the organization. Managers are expected to demonstrate strong leadership that can boost employees' performances and direct followers to achieve organization goals. This study was conducted to discover the relationship between leadership styles and employees' job performances. Specifically, this paper aims to identify the degree of influence among the three types of leadership styles namely, transformational leadership, transactional leadership, and thought leadership on employees' job performances in the Malaysian private sector. Researchers have conducted many studies on transformational and transactional leadership theories adopted from Full Range Leadership Model developed by (Bass \& Avolio, 1994). However, thought leadership role has started to draw much attention on how leadership styles affect employees' job performances. This article also aims to provide an alternative view that distinguishes from previous researches which focus on different leadership styles used by managers to improve employees' job performances in different settings. A conceptual framework has been developed to examine the impact of the three types of leadership styles on employees' job performances.
\end{abstract}

Keywords: Transformational Leadership, Transactional Leadership, Thought Leadership, Employee Job Performance, Malaysia Private Sector.

\section{Introduction}

Leadership is the capability to influence a group of people to achieve a vision or set of goals. It is a widely studied subject in management. According to Kalsoom, Khan, \& Zubair (2018), leadership is the most critical component in an organization and the most important skill for the organization's leaders. It brings direct and indirect impact to the employee's performance. Othman, Saad, Robani, \& Abdullah (2014) stated that leaders play a crucial role 
to foster a culture that encourages knowledge sharing, employee retention and create loyalty to the organization. In a highly competitive environment, organizations heavily depend on their managers to drive transformation and innovation to gain a competitive advantage over their rivals. Employees are the biggest asset of the organizations. Factors to improve the employees' job performances and well-being have become a big challenge to organizations, particularly leadership. This requires manager to understand the effectiveness and impact of different leadership styles towards employees' performances. Bass and Avolio (1994) introduced the Full Range Leadership model (FRL). The model illustrates the most effective leadership styles are transformational and transactional leadership styles. According to the FRL model, when both leadership styles were use simultaneously it would influence subordinates' behaviour and attitudes which in turn will inspire them to enhance their performances. The FRL model has been validated in many settings such as Thailand (Chaimongkonrojna \& Steane, 2013), United Kingdom and Bulgaria (Paramova \& Blumberg, 2017) and Korea (Kim \& Choi 2004). Several theories have explained on leadership effectiveness. Among all, transformational and transactional leadership styles have strongly correlation with employees' performances (Kirkman, Chen, Farh, Chen, \& Lowe, 2009),

Currently, many organizations face challenges such as high staff turnover rate, lack of commitment and work-related stress among employees (Asrar-ul-haq \& Kuchinke, 2016). This has resulted in low productivity and efficiency to align/ achieve the organizations' goals. In fact, it was reported that Malaysia has one of the highest percentage of productivity losses. (Chu, 2017). Manager's leadership is one of the key factors that ensures the success of an organization. Leaders not only motivate employees to improve their job performances, but also inspire employees to perform more than expected by their job requirements (Nawoselng'ollan \& Roussel, 2017) Therefore, this research posits that manager's leadership role is very crucial to lead the team, motivate and inspire employees to achieve better performances.

However, it was found that there is almost no research conducted on the new leadership approach based on the literature review i.e. thought leadership being studied in relation to employees' job performances. Furthermore, previous studies mainly focused on banking sectors, healthcare, manufacturing lines on FMCG (Fast moving consumer goods) and service lines (hotels) in the context of studies in other foreign countries. According to Yiing \& Ahmad (2009), few studies were done in the Malaysian context, with the exception of a few researchers who conducted the study in the Asian setting. This study intends to provide added value to Malaysia's existing knowledge base. The second research gap highlighted in this research is in theory. The theoretical gap identified for this study is lack of research studies on new leadership style - thought leadership theory. There are ample of research done on transformational leadership, transactional leadership and laissez-faire, discussing on how these leadership styles significantly positively impact on employee job performance. However, there are not many research studies on new evolved leadership i.e. thought leadership and their influence on organizational behavior - employee job performance.

Therefore, this paper endeavours to analyse the impact of the three leadership styles namely, transformational leadership, transactional leadership and thought leadership on employees' job performances. Right leadership helps to reduce the attrition rate (Nanjundeswaras \& 
Swamy, 2014). Hence, this study is conducted to identify which leadership style should the manager adopt in people management, thereby improving employees' job performances. The scope of this research study will be in the Malaysian private sector.

\section{Literature Review and Proposition Development}

Leadership

Leadership is the capability to influence a group of people to achieve a vision or set of goals (Robbins \& Judge 2017; Jong \& Hartog, 2007). It is a widely studied subject in management. According to Kalsoom et al., (2018), leadership is the most critical component in an organization and the most important skill for the organization's leaders. It brings direct and indirect impact to the employee's performance. (Othman et al., 2014) Leadership can better predict/foresee the failure or success of an organization (Asrar-ul-haq \& Kuchinke, 2016). Team performance is an important part that builds up an organization. Individual effort by one or two persons does not progress the organization. Rather, it is brought by joint efforts from all members in the organization. Performance has strong correlation with an organization's strategic goals. Leaders directly influence towards the employees' performances and overall team performances (Othman et al., 2014).

\section{Transformational Leadership}

Transformation leadership can be defined as a situation when one or more person engages with each other where the leaders and followers raise each other level of motivation, thus creating a transforming effect on both leaders and followers (Venkat, 2012; Burn 1978). Transformational leadership focuses on improving employee's development, process oriented, commitment based on trust and expectations. Thus, motivating employees to perform beyond expectation (Hater \& Bass, 1988). Transformational leaders inspire followers to go beyond their self interests and these leaders have extraordinary effect on followers (Robbins \& Judge, 2017). According to Bass and Avolio (1997), transformational leadership have four dimensions which are idealized influence, inspirational motivation, intellectual simulation and individualize consideration.

\section{Transactional Leadership}

Transactional leadership is a leadership style where the leaders lead the followers via punishment and reward (Robbins, Judge, \& Hasham, 2009) for the completion of certain tasks (Bass and Avolio. 1997). Transactional leaders guide and motivate their followers to achieve goals by clarifying roles and task requirements (Robbins \& Judge, 2017). Transactional leaders may result in follower's compliance, but unlikely to generate commitment to task objectives (Nam and Mohammad, 2011). The transactional leader and followers are more towards temporary negotiation process, and it hinders the employees' innovative and creative skills (Dai et. al. 2013). However, transactional leadership were also linked to positive outcomes in the organization (Afshari \& Gibson, 2016) and in some cases, transactional leadership were found to have strong impact on employee outcomes (Podsakoff et al. 2006), thus, transactional leadership style should be taken into account of its contribution towards positive employees' behavior and organization outcome. 


\section{Thought Leadership}

Thought leadership is a type of leadership that is based on power of ideas that transform on how we think. A thought leader promotes new ideas to superiors or peers (Mccrimmon \& Mccrimmon, 2011). A Thought Leader is a leader who inspires others with innovative ideas and turn the ideas into reality and create a network to replicate and scale the ideas into sustainable change (Brosseau, 2013). The notion of thought leadership is the promotion of a new idea that brings change through logical argument, factual demonstration and inspiring appeal (Rausch \& McCrimmon, 2005). A research done by Barry and Gironda (2017) found that Thought Leaders portray abilities such as championing new ideas, able to provoke new mindset in addressing challenge, communicate with clarity on how to turn ideas into reality and able to develop actionable strategies.

\section{Employee Job Performance}

Employee job performance can be defined as the total expected value that an individual brings to the organization of the discrete behavioral episodes which carries out over a standard period of time Motowidlo \& Kell, 2012). It can also be defined as how efficiently employees accomplishes his or her duties (Torlak \& Kuzek, 2019) and are usually measured through multi dimensions (Pradhan \& Jena 2017; Deslie, 2015). Employee performance are usually based on the employee's knowledge, skill, expertise and behaviour necessary to perform the job (Pawirosumarto et. al. 2017). Most organizations place great emphasis on employee job performance as it is an important element in achieving sustainable competitive advantage.

The summary of definitions is shown in Table 1.

Table 1: Leadership definition, transformational leadership, transactional leadership, thought leadership and job performance.

\begin{tabular}{|c|c|}
\hline Source & Definition \\
\hline $\begin{array}{l}\text { (De Jong \& Den } \\
\text { Hartog, 2007) }\end{array}$ & $\begin{array}{l}\text { Leadership is defined as a process to influence people in order to achieve the } \\
\text { desired results. }\end{array}$ \\
\hline (Hater \& Bass, 1988) & $\begin{array}{l}\text { Transformational leadership focuses on improving employee's development, } \\
\text { process oriented, commitment based on trust and expectations. Transformational } \\
\text { leader's responsibility is to motivate employee to perform beyond expectation. }\end{array}$ \\
\hline (Robbins et al., 2009) & $\begin{array}{l}\text { Transactional leadership is a leadership style where the leaders lead the followers } \\
\text { via punishment and reward. Transactional leader's responsibility is on role } \\
\text { clarification and task completion. }\end{array}$ \\
\hline $\begin{array}{l}\text { Motowidlo \& Kell, } \\
\text { 2012) }\end{array}$ & $\begin{array}{l}\text { Thought leadership is a type of leadership that is based on power of ideas that } \\
\text { transform on how we think. A thought leader promotes the new ideas to superiors } \\
\text { or peers. Thought leadership is based on innovation; ideas for new products and } \\
\text { services to convince/influence potential followers. }\end{array}$ \\
\hline $\begin{array}{l}\text { (Motowidlo \& Kell, } \\
\text { 2012) }\end{array}$ & $\begin{array}{l}\text { Job performance is defined as the total expected value that an individual brings to } \\
\text { the organization of the discrete behavioral episodes which carries out over a } \\
\text { standard period. }\end{array}$ \\
\hline
\end{tabular}




\section{Proposition Development}

In this section, relationship between independent variables and dependent variables will be discussed to form a proposed research conceptual framework. Three types of leadership styles will be discussed in relation to employees' job performances.

There are four elements in transformational leadership i.e. inspirational motivation, intellectual stimulation, idealized influence, and individualized consideration (Robbins et al., 2009). Transformational leader has been described as a psychoanalyst, they tend to learn, understand and analyse their employees/followers' mind, attitudes, their thoughts and preference to come to the decision that helps to enhance the employees performance level (Abbas, 2015). A transformational leader motivates employees (Walumbwa, Avolio, \& Zhu, 2008) to move up from their self-interest; gives feedback, set high level of performance standard; assist their employees to become more innovative; and alert to followers' needs. They transform followers' beliefs, values and attitude to achieve performance exceed expectations. This in turns increase employee performance (Buil, Martínez, \& Matute, 2019). Paper from (Kehinde \& Banjo, 2014); (Li \& Hung, 2009) concluded that transformational leadership is the best approach organizations can use to improve employees' performances to meet the company's targeted goals. Hence this study proposed that:

Preposition 1: Transformational leadership style has a positive impact on employee performance

Transactional leadership consist of three elements namely, contingent reward, management by exception active, and management by exception passive (Hargis, Watt, \& Piotrowski, 2011). (Paracha, Qamar, Mirza, \& Waqas, 2012), (Mir \& Shah, 2015) and (Kalsoom et al., 2018) research findings show that transactional leadership style had more significant relationship with employee performance. Effective transactional leadership contributes towards better employee job performance when facing new challenges. There is an exchange relationship exists in this type of leadership style, where employee gives performance to leader, and leader provides abstract reward in the form of respect, trust and commitment as a return. A good transaction process between leaders and followers leads to satisfactory employee job performance. Positive effects occur when followers perceived it positively. In contrast, negative effect will also occur when followers perceived the leader cannot be trusted because they failed to keep their promise, conducting non-transparent or dishonest behavior (Bass \& Avolio, 1994). Hence this study proposed that:

Preposition 2: Transactional leadership has a positive impact on employee performance

Thought leadership has no hierarchy and no one manages anyone. It has been described as a person's ability to motivate others to come up with new ideas and change the way things are done by transforming the organization. Thought leader builds a platform and system that include method, process, guidelines or set of best practices for people to follow and shape their success besides persuade people to new way of thinking. Followership is built to create influence and trust. Employees feel motivated and will challenge themselves to come out with new ideas when they are recognized under thought leadership. This in turns will increase employee job performance (Iddrisu, 2017). Based on the above discussion, this study proposed that: 
Preposition 3: Though leadership has a positive impact on employee performance.

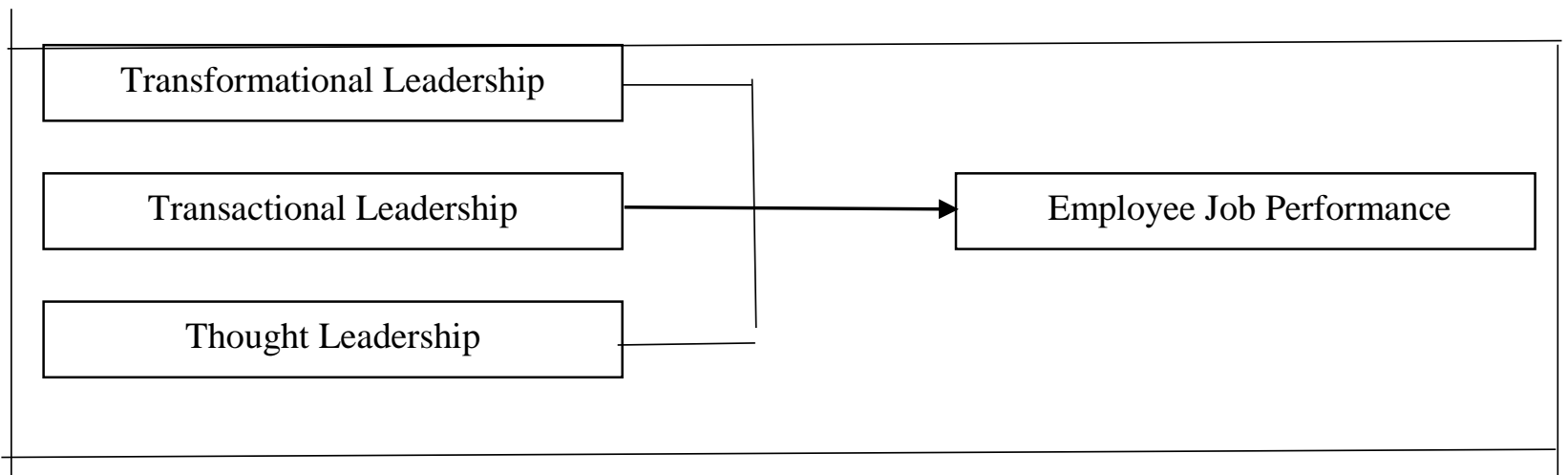

Figure 1: Proposed research framework

Figure 1 depicts the proposed model and the relationships between the variables. In this study, the endogenous variable proposed are the employee's job performance. The exogenous variable in this model is Transformational Leadership which consists of four dimensions namely idealized influence, inspirational motivation, intellectual simulation and individualized consideration. The second exogenous variable in this framework is Transactional Leadership followed by Thought Leadership.

\section{Methodology}

\section{Sample and Data Collection}

The targeted population for this study would be employees working in the Malaysian private sector. Employees holding managerial and non-managerial position will be selected as respondents in this study. The inclusion criterion is the employees must have at least 3 years of working experience as they have been exposed to different types of leadership in their workplace employees. Self- administered questionnaires will be the main method of data collection. Prior to receiving the questionnaire, participants will be given a cover letter explaining the purpose and to assure the respondents of their confidentiality.

\section{Measures}

In assessing transformation leadership this study will use the 20 items from the multifactor leadership questionnaire developed by Bass and Avolio (1997). This measurement has four dimensions that are: idealized influence, inspirational motivation, intellectual stimulation and individualized consideration. The transactional leadership items will be also be adopted from the Multifactor Leadership Questionnaire by Bass and Avolio (1997) which include three dimensions that are: contingent reward, management by exception and Laissez-Faire. In relation to Thought Leadership, the items will be adopted from study done by Barry \& Giroda (2017). The items for Employee Performance will adopted the measurement from Pradhan et al. (2017) study which consists of three dimensions - task, adaptive and contextual performance.

\section{Data Analysis}

The data gathered from this sample will be analyzed using Statistical Package for Social Science (SPSS) and Smart PLS 3.2.8 (Ringle et al., 2015). Descriptive statistics such as mean, standard deviation and correlation coefficients will be analyzed using SPSS. As for the 
assessment of measurement model the validity and reliability of items be executed via Smart PLS 3.2.8. Once the validity and reliability of the constructs are established, this study will examine the structural model of this study as shown in Figure 1.

\section{Discussion}

Literature findings collected from this paper provides an exposure on the impact of transactional leadership, transformational leadership, and thought leadership as the elements to increase employees' job performances in the Malaysian private sector. Leadership style affects employees' performances in many ways. The research findings demonstrated there is a relationship between leadership styles and job performances within an organization. Fear management creates stress that can produce the desired outcome in the short term while this success is not sustainable in the long run. On the other hand, a leader who inculcate trust and open working environment where information is shared will form an organization that can take up to any challenge. Thought leadership has recently started to draw much attention. Thought leadership is made from two main pillars which are novelty and trust. They generate innovative ideas, trustworthy and authority. In conclusion, there is no ideal leadership style for each situation. It is important for organization leaders to review and identify which leadership style has more significant relationship with employees' job performances that fit in their organization. The proposed research framework is shown in Figure 1.

\section{Recommendations and Research Limitations}

The proposed prepositions once being tested empirically would provide insights for the type of leadership styles can be used to lead employees to achieve better job performance. Once the prepositions were tested, leaders would be able to see which leadership styles would enhance employees' job performances. Effective leadership is important to an organization viability as leaders create the process for achieving goals, aligning procedures (Mastrangelo, 2004).

First, literature review of which this study propositions were based, relied on a relatively small pool of existing empirical especially in the area of Thought Leadership is limited in scope and breath. Hence it is proposed that more future more research is needed before generalizing the result of this study. Secondly, this research has not been empirically tested yet. This research would suggest that future researchers to test the proposed framework empirically. The empirical results gathered would be a great contribution to the subject of Leadership and employees' job performances.

\section{Conclusion}

In this research, a review of the of the existing literature on leadership has been conducted to identify the type of leadership styles that have an impact on Employee Job Performance. This research posits that transactional, transformational and thought leadership would pose a positive impact on employees' job performances. Three research propositions have been developed to examine the causal relationship proposed in this research. More importantly, this paper provides an insight for scholarly research in the field of leadership, especially Thought Leadership, which is deficient in theoretical and empirical research, and offers 
managers a framework to apply the most suitable leadership styles in improving employees' job performances.

\section{References}

Abbas, Q. (2015). Effect of Leadership Development on Employee Performance in Pakistan. Pakistan Economic and Social Review 47(2), 269-262. https://doi.org/10.4172/22235833.1000146

Asrar-ul-haq, M., \& Kuchinke, K. P. (2016). Impact of leadership styles on employees ' attitude towards their leader and performance : Empirical evidence from Pakistani banks. Future Business Journal, 2(1), 54-64. doi.org/10.1016/j.fbj.2016.05.002

Bass, B., \& Avolio, B. (1994). Improving organizational effectiveness. Improving organizational effectiveness through transformational leadership. London: Sage Publication

Barry, J. M., \& Gironda, J. T. (2017). Operationalizing thought leadership for online B2B marketing. Industrial Marketing Management, Article in-Press. doi.org/10.1016/j.indmarman.2017.11.005

Buil, I., Martínez, E., \& Matute, J. (2019). Transformational leadership and employee performance. The role of identification, engagement and proactive personality, International Journal of Hospitality Management, 77, 64-75. doi.org/10.1016/j.ijhm.2018.06.014

Burns, J. M. (1978). Leadership.NY: Harper \& Row.

Dai, Y., Dai, Y., Chen, K. \& Wu, H. (2013). Transformational vs transactional leadership: which is better?, International Journal of Contemporary Hospitality Management, 25(5), 760-778. doi.org/10.1108/IJCHM-Dec-2011-0223

Jong, D. J. P. J., \& Hartog, D. N. (2007). How leaders influence employees' innovative behaviour. European Journal of Innovation Management, 10 (1). doi.org/10.1108/14601060710720546

Chaimongkonrojna T., \& Steane, P. (2015) Effectivenss of full range leadership development among middle managers. Journal of Management Development, 34(9), 1161-1180. doi.org/10.1108/JMD-01-2014-0002

Chu, M. F. (2017). Survey: Malaysian work most hours but are less productive. The Star. 17 Nov 2017 https://www.thestar.com.my/news/nation/2017/11/17/survey-malaysianswork-most-hours-but-are-least-productive/

Deslie, N. (2015). The Impact of Leadership Style on Employee Performance, 3-49. Hargis, M. B., Watt, J. D., \& Piotrowski, C. (2011). Developing Leaders: Examining the Role of Transactional and Transformational Leadership Across Contexts Business. Organization Development Journal 29(3) 51-68-7.2 doi.org/10.1360/zd-2013-43-61064

Hater, J. J., \& Bass, B. M. (1988). Superiors' Evaluations and Subordinates' Perceptions of Transformational and Transactional Leadership. Journal of Applied Psychology 73, 695702 doi.org/10.1037/0021-9010.73.4.695

Kalsoom, Z., Khan, M. A., \& Zubair, S. S. (2018). Impact of Transactional Leadership and Transformational Leadership on Employee Performance: A Case of FMCG Industry of Pakistan Impact of Transactional Leadership and Transformational Leadership on Employee Performance: A Case of FMCG Industry of Pakistan. Industrial Engineering Letters, 8(3), 23-30 
Kehinde, O., \& Banjo, H. (2014). A test of the impact of leadership styles on employee performance: A study of department of petroleum resources. International Journal of Management Sciences, 2(3), 149-160.

Kim, D. and Choi, C. (2004). Developing future leaders at Hyundai Motor Company through blended learning. Industrial and Commercial Training, 36 (7),286-290. https://doi.org/10.1108/00197850410563920

Kirkman, B., Chen, G., Farh, J. L., Chen, Z. X., \& Lowe, K. (2009). Individual power distance orientation and follower reactions to transformational leaders: A cross-level, crosscultural examination. Academy of Management Journal, 52(4), 744-764 doi.org/10.5465/AMJ.2009.43669971

Li, C. K., \& Hung, C. H. (2009). The influence of transformational leadership on workplace relationships and job performance. Social Behavior and Personality: An International Journal 37(8), 1129-1142. doi.org/10.2224/sbp.2009.37.8.1129

Mccrimmon, M., \& Mccrimmon, M. (2011). Thought leadership: a radical departure from traditional, positional leadership. Management Decision 43(7/8). doi.org/10.1108/00251740510610062

Mir, S., \& Shah, M. (2015). Transactional Leadership and Job Performance : An Empirical Transactional Leadership and Job Performance : An Empirical Investigation. Sukkur IBA Journal of Management and Business 2, 74-85. doi.org/10.30537/sijmb.v2i2.94

Mastrangelo, A., Eddy, E. and Lorenzet, S. (2004). The importance of personal and professional leadership. Leadership \& Organization Development Journal, 25 (5), 435451.

Motowidlo, S. J., \& Kell, H. J. (2012). Chapter 5 Job Performance. Handbook of Psychology. doi.org/10.1002/0471264385.wei1203

Na-Nan, K., Chaiprasit, K. \& Pukkeeree, P. (2018). Factor analysis-validated comprehensive employee job performance scale. International Journal of Quality \& Reliability Management, 35(10), 2436-2449. doi.org/10.1108/IJQRM-06-2017-0117

Nam, N. \& Mohamed, S. (2011). Leadership behaviors, organizational culture and knowledge management practices. Journal of Management Development, 30 (2), 206-221. doi.org/10.1108/02621711111105786

Nanjundeswaras, T. S., \& Swamy, D. R. (2014). Leadership styles, 7(2), 57-63.

Nawoselng'ollan, D., \& Roussel, J. (2017). Influence of Leadership Styles on Employees' Performance: A Study of Turkana County, Kenya. International Journal of Business and Social Science 8 (7), 82-98

Othman, F. S., Saad, M. S. M., Robani, A., \& Abdullah, A. N. (2014). A Conceptual Framework of The Impact of Leadership Styles on Heterogeneous R\&D Team Performance. International Symposium on Research in Innovation and Sustainability, (Special issue), 1759-1762.

Paracha, M. U., Qamar, A., Mirza, A., \& Waqas, I. U. H. (2012). Impact of Leadership Style (Transformational \&amp; Transactional Leadership) On Employee Performance \&amp; Mediating Role of Job Satisfaction. Study of Private School (Educator) In Pakistan. Global Journal of Management and Business Research 12 (4), 55-64 https://doi.org/http://creativecommons.org/licenses/by-nc/3.0/)

Pawirosumarto, S., Sarjana, P. and Muchtar, M. (2017). Factors affecting employee performance of PT.Kiyokuni Indonesia. International Journal of Law and Management, 59(4), 602-614. doi.org/10.1108/IJLMA-03-2016-0031 
Podsakoff, P. M., Bommer, W. H., Podsakoff, N. P. and MacKenzie, S. B. (2006). Relationships between leader reward and punishment behavior and subordinates' attitudes, perceptions, and behaviors: A meta-analytic review of existing and new research. Organizational Behavior and Human Decision Processes, 99 (2), 113-142.

Paramova, P., \& Blumberg, H. (2017). Cross-Cultural Variation in Political Leadership Styles. Europe's Journal of Psychology, 13(4), 749-766. doi:10.5964/ejop.v13i4.1412

Pradhan, Rabindra \& Jena, Lalatendu. (2016). Employee Performance at Workplace: Conceptual Model and Empirical Validation. Business Perspectives and Research, 5. 117. https:// 10.1177/2278533716671630

Rausch, E. and McCrimmon, M. (2005). Thought leadership: a radical departure from traditional, positional leadership, Management Decision 43 (7/8), 1064-1070. https://doi.org/10.1108/00251740510610062

Ringle, Christian, M., Wende, Sven, \& Becker, Jan-Michael. (2015). SmartPLS 3. Bönningstedt: SmartPLS. Retrieved from http://www.smartpls.com

Robbins, S. T., Judge, T. A, \& Hasham, E. S. (2009). Organizational Behavior. Arab World Edition Pearson Education Limited.

Robbins, S. \& Judge, T. A, (2017). Organizational Behavior. 13th Edition. Essex: Pearson Education Limited.

Torlak, N.G. \& Kuzey, C. (2019). Leadership, job satisfaction and performance links in private education institutes of Pakistan. International Journal of Productivity and Performance Management 68(2), 276-295

Venkat R. K. (2012). Transformational leadership and personal outcomes: Empowerment as mediator. Leadership \& Organization Development Journal, 33(6) 550 - 563

Walumbwa, F. O., Avolio, B. J., \& Zhu, W. (2008). How transformational leadership weaves its influence on individual job performance: The role of identification and efficacy beliefs. Personnel Psychology 61(4), 793-825

Yiing, L. H., \& Ahmad, K. Z. B. (2009). The moderating effects of organizational culture on the relationships between leadership behaviour and organizational commitment and between organizational commitment and job satisfaction and performance. Leadership and Organization Development Journal, 30(1), 53-86. https://doi.org/10.1108/01437730910927106 